\title{
Random coil shifts of posttranslationally modified amino acids
}

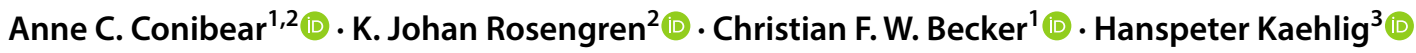

Received: 22 April 2019 / Accepted: 9 July 2019 / Published online: 17 July 2019

(c) The Author(s) 2019

\begin{abstract}
Most eukaryotic proteins are modified during and/or after translation, regulating their structure, function and localisation. The role of posttranslational modifications (PTMs) in both normal cellular processes and in diseases is already well recognised and methods for detection of PTMs and generation of specifically modified proteins have developed rapidly over the last decade. However, structural consequences of PTMs and their specific effects on protein dynamics and function are not well understood. Furthermore, while random coil NMR chemical shifts of the 20 standard amino acids are available and widely used for residue assignment, dihedral angle predictions and identification of structural elements or propensity, they are not available for most posttranslationally modified amino acids. Here, we synthesised a set of random coil peptides containing common naturally occurring PTMs and determined their random coil NMR chemical shifts under standardised conditions. We highlight unique NMR signatures of posttranslationally modified residues and their effects on neighbouring residues. This comprehensive dataset complements established random coil shift datasets of the 20 standard amino acids and will facilitate identification and assignment of posttranslationally modified residues. The random coil shifts will also aid in determination of secondary structure elements and prediction of structural parameters of proteins and peptides containing PTMs.
\end{abstract}

Keywords Nuclear magnetic resonance spectroscopy $\cdot$ Peptides $\cdot$ Posttranslational modification $\cdot$ Protein modification · Random coil shifts $\cdot$ Secondary structure

\section{Introduction}

Posttranslational modifications (PTMs) expand the complexity of the proteome and their role in altering protein function and regulation is well recognised (Walsh et al. 2005; Aebersold et al. 2018). Addition of small chemical functionalities (e.g. phosphate-, acetyl-, methyl-groups etc.), or more complex molecules such as carbohydrates or other

Electronic supplementary material The online version of this article (https://doi.org/10.1007/s10858-019-00270-4) contains supplementary material, which is available to authorized users.

Anne C. Conibear

a.conibear@uq.edu.au

1 Faculty of Chemistry, Institute of Biological Chemistry, University of Vienna, Währinger Straße 38, 1090 Vienna, Austria

2 School of Biomedical Sciences, The University of Queensland, QLD 4072 Brisbane, Australia

3 Faculty of Chemistry, Institute of Organic Chemistry, University of Vienna, Währinger Straße 38, 1090 Vienna, Austria polypeptides to proteins, in a controlled fashion, regulates fundamental cellular processes like transcription, cellular signalling and protein homeostasis. For example, a delicate balance between PTM addition and removal at specific locations and in particular combinations on histone proteins regulates the compactness of chromatin and thereby the rate of transcription (Muller and Muir 2015). Furthermore, errors in addition, removal or location of PTMs can lead to protein dysregulation and are increasingly associated with disease processes. For example, modification of the Parkinson's disease-associated protein $\alpha$-synuclein with the carbohydrate $O$-GlcNAc tends to inhibit the formation of toxic aggregates (Lewis et al. 2017). The Alzheimer's disease-associated protein Tau-4 is also known to be extensively modified and the cross-talk between phosphorylation and glycosylation modifications has been studied using NMR spectroscopy (Bourre et al. 2018). Furthermore, incorporation of carboxymethyllysine in the central repeat region increased aggregation of Tau- 4 but incorporation of phosphoserine decreased aggregation (Ellmer et al. 2019). These, amongst many other studies, illustrate the importance of understanding the role of PTMs in protein structure and function. 
The role of PTMs is largely underrepresented in structural biology, although protein NMR spectroscopy is well suited to studying structural and dynamic properties of proteins in near-native conditions (Theillet et al. 2012a). Our understanding of the prevalence and diversity of PTMs has grown with developments in mass spectrometry and antibody-based techniques for detecting and locating PTMs on proteins and tens of thousands of proteins in the SwissProt database are annotated with PTMs (Aebersold et al. 2018). NMR spectroscopy studies, however, are predominantly carried out using recombinant proteins that lack the relevant PTMs. Access to posttranslationally modified proteins is now facilitated by recent developments in protein chemical synthesis (Conibear et al. 2018), genetic code engineering (Liu and Schultz 2010; Lang and Chin 2014) and enzymatic protein modification (Zhang et al. 2018), enabling studies of the role of PTMs in protein structure and function. Furthermore, increased commercial availability of the requisite building blocks for solid phase peptide synthesis (SPPS) means that peptides and proteins bearing PTMs are finding application in the pharmaceutical industry, chemical biology and peptide-based materials (Barber and Rinehart 2018).

Random coil chemical shifts are widely used in NMR structural biology of proteins and peptides but have only been determined for the 20 standard amino acids (Wishart et al. 1995; Schwarzinger et al. 2000), with the exception of three phosphorylated residues (Bienkiewicz and Lumb 1999). Several sets of random coil NMR chemical shifts obtained under a number of conditions are available, and readers are directed to two extensive reviews for a comparison of the datasets, advice on choosing an appropriate set of values and their various applications (Wishart and Nip 1998; Mielke and Krishnan 2009). The majority of random coil shifts has been determined using glycine or alanine as flanking residues but glutamine has also been suggested as a flanking residue that might provide better predictions of Ramachandran distribution (Ting et al. 2010; Kjaergaard and Poulsen 2011). In addition to aiding spectral assignment, comparison of measured chemical shifts with random coil shifts can give an indication of secondary structural elements, hydrogen bonding, oxidation states, protonation states and structural propensity of disordered regions (Mielke and Krishnan 2004, 2009). Recently, characteristic chemical shift patterns have been used to determine NMR sequence tags that can be used to sequence peptides or small proteins such as conotoxins by comparison with a sequence database (Wilson and Daly 2018).

Much work has been directed towards deriving structural restraints from chemical shifts for use in protein structure calculations and being able to predict protein structure from chemical shift data. Most of these approaches use secondary chemical shifts (the difference between an observed chemical shift and the respective random coil value) as the initial input data. The chemical shift index (CSI) has been widely used to predict the type and location of secondary structural elements in proteins from ${ }^{1} \mathrm{H}$ chemical shifts (Wishart et al. 1992); although not strictly secondary shifts, the deviation of the $\mathrm{H} \alpha$ shifts from a table of mid-point reference $\mathrm{H} \alpha$ shift ranges is calculated for each residue and used to allocate it a score (Wishart et al. 1992). The widely-used programme TALOS-N (Shen and Bax 2013), and its predecessors TALOS + (Shen et al. 2009) and TALOS (Cornilescu et al. 1999), predicts backbone $\varphi$ and $\psi$ angles, as well as some side-chain $\chi_{1}$ angles, by matching secondary chemical shifts of peptide segments to those in a database. Furthermore, an $S^{2}$ model-free order parameter is predicted that can indicate the flexibility of a protein region (Berjanskii and Wishart 2005). These predictions are used to validate structures derived from NOE correlations or are added as additional restraints in protein structure calculations. Another example of a prediction tool that uses secondary chemical shift input data is 'DISH', a method for predicting the dihedral angles of cystine side chains and disulfide bond conformations (Armstrong et al. 2018). Finally methods such as CSROSETTA (Shen et al. 2008, 2009) utilise chemical shifts for de novo structure determination of proteins, and more specialised approaches focussing on disulfide-rich peptides have also been described recently (Wang and Craik 2019). For proteins containing PTMs, the lack of random coil reference values of posttranslationally modified residues means that predictions for some residues cannot be made, or are compromised by using the random coil shift of the corresponding unmodified residue. This affects both the modified residue and its neighbours, and can prevent, or lead to inaccurate, structural predictions for these residues.

Random coil shifts of posttranslationally modified residues have not been systematically characterised, although several studies have highlighted distinctive NMR features of PTMs and random coil shifts of phosphorylated serine, threonine and tyrosine have been determined (Bienkiewicz and Lumb 1999). A dataset of observed ${ }^{1} \mathrm{H}$ and ${ }^{13} \mathrm{C}$ chemical shifts of posttranslationally modified residues in conotoxins was compiled and analysed by Marx et al. (2006), providing a useful reference for studies of conotoxins. This dataset, however, was derived from folded peptides with defined structures and so does not have the same broad applications as random coil chemical shifts. A novel method for identification of PTMs, especially glycosylation, on unlabelled protein samples was introduced by Schubert et al., involving denaturation of glycosylated proteins and identification of the distinct NMR fingerprint patterns of the glycosyl moieties (Schubert et al. 2015). NMR signatures of N-terminal gluconoylation have also been reported and should be useful for identifying this PTM, which is common in recombinantly expressed His-tagged proteins (Schweida et al. 2019). The value of NMR spectroscopy for monitoring 
protein modification and associated changes in protein structure has been illustrated in several studies by Selenko and co-workers (Dose et al. 2011; Liokatis et al. 2010; Theillet et al. 2012, 2013). For example, they showed that lysine $\mathrm{CH}_{2} \varepsilon$ resonances can be used to distinguish acetylation and methylation events and were able to monitor the kinetics of the modification in the complex environment of cell extracts (Theillet et al. 2012b).

Here we present a set of random coil NMR chemical shifts of common posttranslationally modified residues for use in assignment and secondary structure determination of modified proteins and peptides and identification of protein PTMs. We selected the modified residues based on their prevalence in eukaryotic proteins, their commercial availability, and their stability and ease of incorporation into proteins and peptides by SPPS. The set of random coil peptides was synthesised by SPPS and the ${ }^{1} \mathrm{H},{ }^{13} \mathrm{C}$ and ${ }^{15} \mathrm{~N}$ chemical shifts were determined in $9: 1 \mathrm{H}_{2} \mathrm{O} / \mathrm{D}_{2} \mathrm{O}$ at $\mathrm{pH}$. The $\mathrm{pH}$ dependence of chemical shifts in $\gamma$-carboxyglutamate and carboxymethyl lysine was also determined. We present the random coil shifts and compare them with those of the corresponding unmodified residues, highlighting some distinctive characteristics of the modified residues. The random coil shifts of posttranslationally modified residues can be applied to any protein and used in combination with established random coil shifts of standard residues to facilitate our understanding of the role of PTMs in protein structure and function.

\section{Materials and methods}

\section{Solid phase peptide synthesis of random coil peptides}

The random coil peptides $\mathrm{Ac}-\mathrm{G}-\mathrm{G}-\mathrm{X}-\mathrm{G}-\mathrm{G}-\mathrm{NH}_{2}$, where ' $\mathrm{X}$ ' is the modified or unmodified residue of interest, were synthesised either manually or on an automated microwave peptide synthesiser (Liberty Blue, CEM, methods in Supplementary Information Table S1) on Rink amide resin at $0.05 \mathrm{mmol} \mathrm{scale}$ according to the following procedure. Special procedures for particular modified residues or protecting groups are detailed in Table S1. 9-fluorenylmethoxycarbonyl (Fmoc)-protected building blocks (listed in Table S1, 2.5 eq.) were manually coupled using 2-(1H-benzotriazol-1-yl)-1,1,3,3-tetramethyluronium hexafluorophosphate (HBTU, 2.4 eq., $0.5 \mathrm{M}$ in DMF) as activator in combination with diisopropylethylamine (DIPEA, 5 eq.) as base under rotation at room temperature for 20-30 min. N-terminal deprotection was achieved with piperidine [ $20 \%$ in dimethylformamide (DMF), $2 \times 5 \mathrm{~min}$ ]. After removal of the Fmoc protecting group, the final $\mathrm{N}$-terminal glycine was acetylated with acetic anhydride/
DCM/DIPEA 10:85:5 ( $2 \times 5 \mathrm{~min})$. The resin was dried and the peptide cleaved from the resin with trifluoroacetic acid (TFA)/triisopropylsilane(TIPS)/ $\mathrm{H}_{2} \mathrm{O}$ 95:2.5:2.5 for $2 \mathrm{~h}$ and then precipitated with diethyl ether and pelleted by centrifugation. The crude peptide was dissolved in acetonitrile/ water 1:1 and lyophilised 2-3 times to remove volatile components from the cleavage, before analysis by ESI-MS in positive ion mode. Specific methods for particular modified residues and supplier details are given in Table S1.

\section{NMR data collection and processing}

Samples for NMR data collection were prepared by dissolving the crude lyophilised peptide $(3-5 \mathrm{mg})$ in $600 \mu \mathrm{L}$ $\mathrm{H}_{2} \mathrm{O} / \mathrm{D}_{2} \mathrm{O}$ 9:1 containing $166 \mu \mathrm{M}$ 2,2-dimethyl-2-silapentane-5-sulfonate sodium salt (DSS) as an internal reference (Wishart et al. 1995). All peptides were sufficiently pure to allow unambiguous peak assignments. The $\mathrm{pH}$ was carefully adjusted to $\mathrm{pH} 5.0 \pm 0.3$ with $\mathrm{NaOH}$ and $\mathrm{HCl}$, using a calibrated $\mathrm{pH}$ meter with a microelectrode. Masses of crude peptide and $\mathrm{pH}$ of each sample are given in Table S2.

NMR spectra were acquired at the University of Vienna NMR Centre on an Avance III HDX 700 MHz NMR spectrometer (Bruker BioSpin, Germany) equipped with an inverse helium cooled quadruple cryoprobe (QCI-F) with a resonance frequency of $700.40 \mathrm{MHz}$ for ${ }^{1} \mathrm{H}, 176.12 \mathrm{MHz}$ for ${ }^{13} \mathrm{C}$, and $70.97 \mathrm{MHz}$ for ${ }^{15} \mathrm{~N}$, respectively. Spectra were acquired at $298 \mathrm{~K}$ and standard Bruker pulse sequences were used with water suppression by either presaturation or 3-9-19 WATERGATE. Spectra acquired for each peptide included: ${ }^{1} \mathrm{H}$ (zgpr); ${ }^{1} \mathrm{H}-{ }^{15} \mathrm{~N}$ HSQC (hsqcetgpsi2); ${ }^{1} \mathrm{H}-{ }^{1} \mathrm{H}$ TOCSY (mlevgpph19, D9 isotropic mixing time $=100 \mathrm{~ms}$ ); ${ }^{1} \mathrm{H}-{ }^{1} \mathrm{H}$ NOESY (noesygpph19, D8 mixing time $=800 \mathrm{~ms}$ ) $;{ }^{1} \mathrm{H}-{ }^{13} \mathrm{C}$ HSQC (hsqcetgp); ${ }^{1} \mathrm{H}-{ }^{13} \mathrm{C}$ HMBC (hmbcgplpndprqf). Sweep widths were generally ${ }^{1} \mathrm{H} 11.0 \mathrm{ppm},{ }^{13} \mathrm{C} 60.0 \mathrm{ppm}$ for HSQC, $180.0 \mathrm{ppm}$ for $\mathrm{HMBC}$, and ${ }^{15} \mathrm{~N} 36.0 \mathrm{ppm}$ The total time to acquire all six spectra was approximately $15 \mathrm{~h}$ per peptide.

Spectra were Fourier transformed, phased and calibrated on the DSS signal $\left({ }^{1} \mathrm{H}\right.$ at $0 \mathrm{ppm}$ ) in Topspin (Bruker BioSpin, Germany). ${ }^{15} \mathrm{~N}$ and ${ }^{13} \mathrm{C}$ spectra were calibrated on the unified scale according to the IUPAC recommendations (Wishart et al. 1995; Harris et al. 2008), using a ratio of 0.251449530 for ${ }^{13} \mathrm{C}$ and 0.101329118 for ${ }^{15} \mathrm{~N}$. Spectra were assigned in CCP-NMR (Vranken et al. 2005), independently of previously assigned random coil shifts. ${ }^{1} \mathrm{H}$ shifts were assigned based on spin system identification using TOCSY spectra and $\mathrm{d} \alpha \mathrm{N}(i, i+1)$ connectivities were assigned using the sequential assignment protocol in the NOESY spectra (Wüthrich 1986). ${ }^{15} \mathrm{~N}$ and ${ }^{13} \mathrm{C}$ chemical shifts were derived from $\mathrm{HSQC}$ and $\mathrm{HMBC}$ spectra. 


\section{pH titrations}

Samples of peptides containing $\gamma$-carboxyglutamic acid and carboxymethyl lysine as residue ' $\mathrm{X}$ ' were prepared as above and the $\mathrm{pH}$ was adjusted to $\mathrm{pH} 2.0$ with $\mathrm{HCl}$. NMR spectra were acquired at the Centre for Advanced Imaging (The University of Queensland) on an Avance $700 \mathrm{MHz}$ NMR spectrometer (Bruker BioSpin, Germany) with a cryoprobe. At $\mathrm{pH} 2.0$ and at $\mathrm{pH} 9.0,{ }^{1} \mathrm{H},{ }^{1} \mathrm{H}-{ }^{1} \mathrm{H}$ TOCSY, ${ }^{1} \mathrm{H}-{ }^{15} \mathrm{~N}$ HSQC,${ }^{1} \mathrm{H}-{ }^{13} \mathrm{C}$ HSQC and ${ }^{1} \mathrm{H}-{ }^{13} \mathrm{C}$ HMBC spectra were acquired to enable assignment of the ${ }^{1} \mathrm{H},{ }^{15} \mathrm{~N}$ and ${ }^{13} \mathrm{C}$ resonances at the extreme $\mathrm{pH}$ values. The $\mathrm{pH}$ was then increased in $\sim 0.5$ steps using $0.1 \mathrm{M} \mathrm{HCl}$ and $0.1 \mathrm{M} \mathrm{NaOH}$ and ${ }^{1} \mathrm{H}$ and ${ }^{1} \mathrm{H}-{ }^{1} \mathrm{H}$ TOCSY spectra were acquired at each step to provide ${ }^{1} \mathrm{H}$ chemical shifts. Spectra were processed, referenced and assigned as above.

\section{Results and discussion}

\section{Design and synthesis of random coil peptides}

The amino acids bearing PTMs (Fig. 1) were selected based on their relevance as naturally occurring protein PTMs, their stability and the availability of suitably protected building blocks for SPPS (Table S1). Random coil peptides were designed based on a commonly used peptide design (Fig. 1) (Schwarzinger et al. 2000; Bienkiewicz and Lumb 1999; Plaxco et al. 1997; Schwarzinger et al. 2001), comprising the modified residue flanked by two glycine residues and the $\mathrm{N}$ - and C-termini blocked as the acetyl and amide derivatives, respectively, to prevent interactions of the charged termini. The peptides were synthesised by manual or automated Fmoc-based SPPS and peptides containing the corresponding unmodified residues were synthesised as controls.

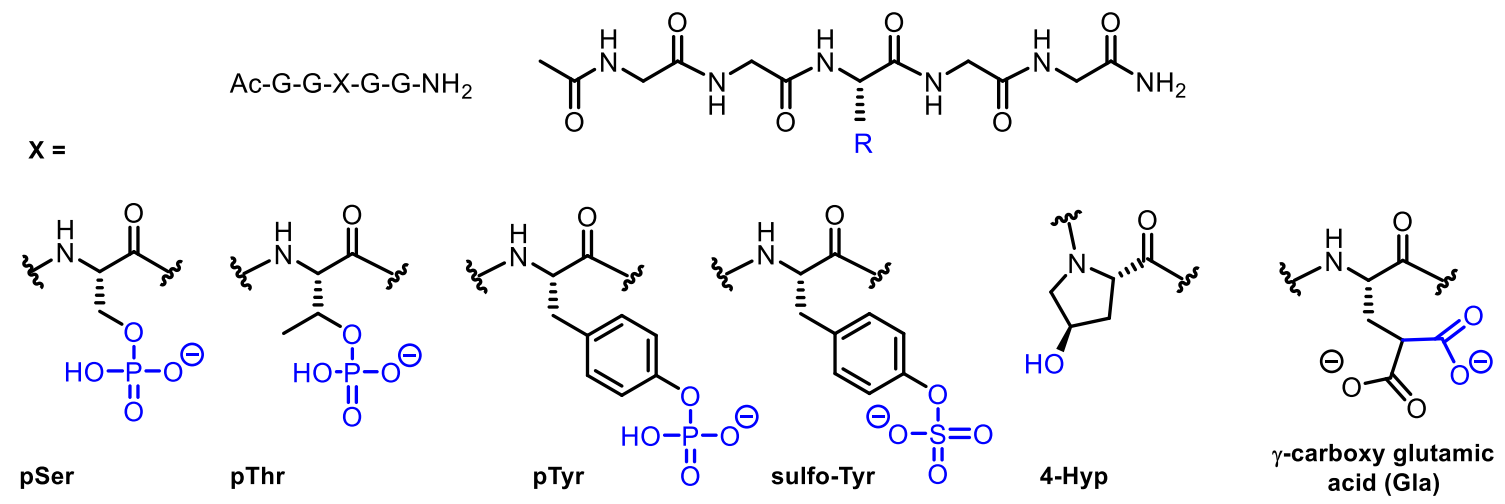<smiles>CCNC(CCCNC(=NC)NC)C(=O)CC</smiles>

$\operatorname{Arg}(\mathrm{Me})_{2}$ symmetric<smiles>CCC(=O)C(CCCNC(=N)N(C)C)NC</smiles>

$\operatorname{Arg}(\mathrm{Me})_{2}$ asymmetric<smiles>CCN[C@@H](CCCNC(N)=[18O])C(=O)CC</smiles>

$\operatorname{Arg}(\mathrm{Me})$<smiles>CNC(CCCC[NH2+]C)C(C)=O</smiles>

MeLys<smiles>CN[C@@H](CCCCN(C)C)C(C)=O</smiles>

$(\mathrm{Me})_{2}$ Lys<smiles>CCCC(NC)C(=O)CCCCN(C)C</smiles>

(Me) ${ }_{3}$ Lys<smiles>CCNC(CCCNC(N)=O)C(=O)CC</smiles>

Cit<smiles>CCCC(NCCCNc1nc(C)c(O)c(CC)n1)C(=O)CC</smiles><smiles>CCC(=O)N[C@@H](CC(=O)NC(NC(C)=O)C(O)CO)C(=O)O</smiles>

Asn(GIcNAc)

Fig. 1 Random coil peptide design and structures of the modified amino acids included in this study. PTMs are highlighted in blue. Protonation states at $\mathrm{pH} 5.0$ are estimated based on available $\mathrm{pK}_{\mathrm{a}}$ values 
Most of the modified amino acid building blocks can be easily incorporated using standard Fmoc SPPS protocols, with some requiring additional steps to remove protecting groups (Table S1). The set of random coil peptides was successfully synthesised and was characterised by mass spectrometry (structures and mass spectra are provided in the Supplementary Information). Due to the size and hydrophilicity of the peptides, purification by RP-HPLC was not possible and the crude peptides were deemed of sufficient purity (approximately $70-95 \%$ based on mass spectrometry and NMR data), for unambiguous assignment of the resonances. We note that other widely-used random coil shift datasets have also been determined using crude peptides, but analytical data were not published for comparison (Schwarzinger et al. 2000; Plaxco et al. 1997).

\section{Assignment of random coil chemical shifts}

Samples for NMR spectroscopy $(\sim 15 \mathrm{mM})$ were prepared in $\mathrm{H}_{2} \mathrm{O} / \mathrm{D}_{2} \mathrm{O}$ 9:1 at $\mathrm{pH} 5.0 \pm 0.3$ (amounts and $\mathrm{pH}$ for each peptide are shown in Table S2) and were referenced to internal DSS (Wishart et al. 1995). These conditions enable comparison with published random coil shifts of the standard amino acids and allow for assignment of ${ }^{1} \mathrm{H},{ }^{13} \mathrm{C}$ and ${ }^{15} \mathrm{~N}$ chemical shifts at natural abundance. ${ }^{1} \mathrm{H}$, TOCSY, NOESY, ${ }^{15} \mathrm{~N}$-HSQC, ${ }^{13} \mathrm{C}$-HSQC and ${ }^{13} \mathrm{C}$-HMBC spectra were acquired at $298 \mathrm{~K}$ and chemical shifts were assigned using the sequential assignment protocol in CCP-NMR (Vranken et al. 2005; Wüthrich 1986). ${ }^{1} \mathrm{H}$ spectra were acquired at the beginning and end of the set of experiments to ensure that the peptides and modifications were stable under the NMR conditions for the duration of the experiment $(\sim 15 \mathrm{~h})$. Chemical shift assignments for the modified residues and their unmodified counterparts are given in Table 1. Chemical shifts of the flanking glycine residues are given in the Supplementary Information (Table S3).

The ${ }^{1} \mathrm{H}-{ }^{1} \mathrm{H}$ NOESY spectra of the random coil peptides showed only strong $(i, i+1)$ inter-residue crosspeaks, indicating that the peptides are indeed 'random coil' and have no long-range interactions (Bienkiewicz and Lumb 1999; Dyson and Wright 1991). Furthermore, we compared the ${ }^{1} \mathrm{H}$ and ${ }^{13} \mathrm{C}$ spectra of four peptides $(\mathrm{X}=$ serine, phosphoserine, lysine and acetyllysine) acquired in $8 \mathrm{M}$ urea, $\mathrm{pH} 2.3$ with those acquired in water and found no major differences in NOESY crosspeaks or chemical shifts (Table S4, except for phosphoserine-as discussed below), confirming that the peptides are in an extended conformation. These validations of the random coil nature of the peptides used in this study are important for use of the random coil shifts as a standard reference dataset to which the observed chemical shifts of any protein can be compared to identify structural elements.

The assigned random coil shifts in Table 1 were compared with corresponding unmodified residues, the same
PTM on different residues, and literature values. The chemical shifts of the unmodified residues are in good agreement with widely used random coil shifts in the literature (Table S5) (Wishart et al. 1995; Schwarzinger et al. 2000), showing that the set of random coil shifts of modified residues complements and can be used in conjunction with those already established. Comparison of the chemical shifts of modified and unmodified residues (Fig. 2) reveals that, for most of the random coil peptides, addition of a PTM made little or no difference to the backbone chemical shifts of the residue ( $\mathrm{NH}, \mathrm{HN}, \mathrm{H} \alpha, \mathrm{C} \alpha$ and $\mathrm{CO}$ ). This is unsurprising as most PTMs occur at the termini of solvent-exposed side chains, where they are unlikely to alter the shielding of the backbone nuclei. However, modifications of serine and threonine are exceptions; HN shifts downfield by $0.32 \mathrm{ppm}$ for serine and $0.25 \mathrm{ppm}$ for threonine phosphorylation. Furthermore, O-linked glycosylation of threonine by $\mathrm{N}$-acetylgalactosamine causes a $1.3 \mathrm{ppm}$ upfield shift in $\mathrm{NH}$ and a $0.24 \mathrm{ppm}$ downfield shift in $\mathrm{H} \alpha$, which was not observed for $\mathrm{N}$-linked glycosylation of asparagine by $\mathrm{N}$-acetylglucosamine. These changes indicate (transient) hydrogen bond formation between the PTM and the backbone $\mathrm{NH}$, as has been reported for serine phosphorylation (Du et al. 2005) and suggested for O-linked glycosylation, as discussed further below (Martinez-Saez et al. 2017).

\section{Phosphorylation of serine, threonine and tyrosine}

Phosphorylated serine, threonine and tyrosine have random coil chemical shifts (Table 1) in agreement with those reported by Bienkiewicz and Lumb (Bienkiewicz and Lumb 1999). These authors also determined the $\mathrm{pK}_{\mathrm{a}}$ values of phosphoserine $\left(\mathrm{pK}_{\mathrm{a}}=5.96 \pm 0.09\right)$, phosphothreonine $\left(\mathrm{pK}_{\mathrm{a}}=6.30 \pm 0.07\right)$ and phosphotyrosine $\left(\mathrm{pK}_{\mathrm{a}}=5.96 \pm 0.04\right)$ for the equilibrium between the singly and doubly charged phosphate groups, based on changes in the ${ }^{31} \mathrm{P}$ phosphate chemical shift (Bienkiewicz and Lumb 1999; Platzer et al. 2014). Equations for calculation of chemical shifts of residues with ionisable side chains at different $\mathrm{pH}$ values are given in the following references (Bienkiewicz and Lumb 1999; Platzer et al. 2014; McIntosh et al. 2011). Bienkiewicz and Lumb further noted that the chemical shift changes upon phosphorylation, such as the $\sim 0.3 \mathrm{ppm}$ downfield shift of HN (Fig. 3), are similar to those observed when hydrogen bonds form in secondary structures (Bienkiewicz and Lumb 1999). Selenko and co-workers have demonstrated that $2 D$ ${ }^{1} \mathrm{H}-{ }^{15} \mathrm{~N}$ correlation experiments are valuable for monitoring phosphorylation events by NMR, based on this characteristic shift, which is strongly $\mathrm{pH}$ dependent and is due to intra-residue hydrogen bonding between the phosphate and backbone amide groups in unstructured regions (Theillet et al. 2012a; Bienkiewicz and Lumb 1999; Du et al. 2005). In a structured region or hairpin, however, the phosphate 
Table 1 Random coil chemical shifts (ppm) of modified and unmodified residues ' $\mathrm{X}$ '

\begin{tabular}{|c|c|c|c|c|c|c|c|c|}
\hline Residue ' $X$ ' & $\mathrm{NH}$ & $\mathrm{HN}$ & $\mathrm{H} \alpha$ & $\mathrm{H} \beta$ & $\mathrm{C} \alpha$ & $\mathrm{C} \beta$ & $\mathrm{C}=\mathrm{O}$ & Others \\
\hline Ser & 115.9 & 8.40 & 4.50 & $3.88,3.93$ & 58.6 & 63.8 & 175.5 & \\
\hline pSer & 115.9 & 8.72 & 4.58 & $4.12,4.20$ & 57.6 & 66.7 & 175.1 & \\
\hline Thr & 113.1 & 8.22 & 4.39 & 4.31 & 62.0 & 69.8 & 175.7 & $\mathrm{H} \gamma 1.21, \mathrm{C} \gamma 21.5$ \\
\hline pThr & 113.6 & 8.47 & 4.43 & 4.65 & 61.9 & 73.9 & 175.2 & $\mathrm{H} \gamma 1.33, \mathrm{C} \gamma 20.8$ \\
\hline Thr(GalNAc) & 111.8 & 8.39 & 4.63 & 4.42 & 60.5 & 78.1 & 174.9 & $\begin{array}{l}\mathrm{H} \gamma 1.26, \mathrm{C} \gamma 20.6 ; \mathrm{H} 14.93, \mathrm{C} 1101.4 ; \mathrm{H} 24.09, \mathrm{C} 252.7 ; \\
\mathrm{H} 33.90, \mathrm{C} 3 \text { 70.5; } \mathrm{H} 43.97, \mathrm{C} 4 \text { 71.4; } \mathrm{H} 54.02, \mathrm{C} 574.1 ; \\
\mathrm{H}_{2} \mathrm{C} 63.74,3.75, \mathrm{CH}_{2} 6 \text { 64.1; } \mathrm{Ac}(\mathrm{NH} 123.1, \mathrm{HN} 7.92, \mathrm{CO} \\
\left.\text { 177.0, } \mathrm{H}_{3} \mathrm{C} 2.02, \mathrm{CH}_{3} 25.0\right)\end{array}$ \\
\hline Tyr & 120.5 & 8.21 & 4.57 & $2.98,3.08$ & 58.2 & 38.7 & 176.8 & 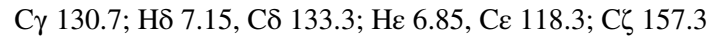 \\
\hline pTyr & 120.2 & 8.24 & 4.61 & $3.02,3.14$ & 58.1 & 38.8 & 176.8 & 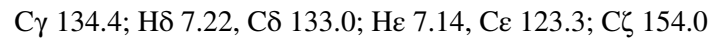 \\
\hline $\operatorname{Tyr}\left(\mathrm{SO}_{3}\right)$ & 120.0 & 8.24 & 4.63 & $3.06,3.18$ & 57.9 & 38.8 & 176.6 & 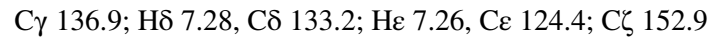 \\
\hline Lys & 120.9 & 8.31 & 4.35 & $1.78,1.88$ & 56.5 & 32.9 & 177.5 & $\mathrm{H} \gamma 1.41,1.46, \mathrm{C} \gamma 24.7 ; \mathrm{H} \delta 1.68, \mathrm{C} \delta 29.0 ; \mathrm{H \varepsilon} 3.00, \mathrm{C} \varepsilon 42.2$ \\
\hline Lys(ac) & 121.4 & 8.28 & 4.31 & $1.74,1.84$ & 56.8 & 33.1 & 177.7 & $\begin{array}{l}\mathrm{H} \gamma 1.34,1.39, \mathrm{C} \gamma 25.1 ; \mathrm{H} \delta 1.51, \mathrm{C} \delta 30.5 ; \mathrm{H \varepsilon} 3.16, \mathrm{C} \varepsilon \\
\quad 42.0 ; \mathrm{H} \zeta 7.94, \mathrm{~N} \zeta 127.3 ; \mathrm{Ac}\left(\mathrm{CO} 176.8 ; \mathrm{H}_{3} \mathrm{C} 1.97, \mathrm{CH}_{3}\right. \\
\text { 24.6) }\end{array}$ \\
\hline Lys $(\mathrm{Me})$ & 120.9 & 8.31 & 4.35 & $1.77,1.88$ & 56.4 & 32.9 & 177.4 & $\begin{array}{l}\mathrm{H} \gamma \text { 1.41, 1.45, C } \gamma 24.7 ; \mathrm{H} \delta 1.69, \mathrm{C} \delta 27.6 ; \mathrm{H \varepsilon} 3.03, \mathrm{C} \varepsilon \\
\quad 51.6 ; \mathrm{H}_{3} \mathrm{C} 2.70, \mathrm{CH}_{3} 35.6\end{array}$ \\
\hline $\operatorname{Lys}(\mathrm{Me})_{2}$ & 120.8 & 8.31 & 4.36 & $1.78,1.89$ & 56.4 & 32.9 & 177.4 & $\begin{array}{l}\mathrm{H} \gamma \text { 1.41, 1.44, C } \gamma 24.6 ; \mathrm{H} \delta 1.73, \mathrm{C} \delta 26.2 ; \mathrm{H \varepsilon} 3.12, \mathrm{C} \varepsilon \\
\quad 60.2 ;\left(\mathrm{H}_{3} \mathrm{C}\right)_{2} 2.86,\left(\mathrm{CH}_{3}\right)_{2} 45.4\end{array}$ \\
\hline $\operatorname{Lys}(\mathrm{Me})_{3}$ & 120.7 & 8.31 & 4.37 & $1.80,1.91$ & 56.3 & 32.9 & 177.4 & $\begin{array}{l}\mathrm{H} \gamma \text { 1.40, 1.45, C } \gamma 24.6 ; \mathrm{H} \delta 1.81, \mathrm{C} \delta 24.5 ; \mathrm{H} \varepsilon 3.31, \mathrm{C} \varepsilon \\
\quad 68.9 ;\left(\mathrm{H}_{3} \mathrm{C}\right)_{3} 3.10,\left(\mathrm{CH}_{3}\right)_{3} 55.5\end{array}$ \\
\hline Carboxymethyl lysine (CML) & 121.0 & 8.31 & 4.35 & $1.78,1.88$ & 56.5 & 32.9 & 177.5 & $\begin{array}{l}\mathrm{H} \gamma 1.42,1.46, \mathrm{C} \gamma 24.8 ; \mathrm{H} \delta 1.72, \mathrm{C} \delta 27.8 ; \mathrm{H \varepsilon} 3.06, \mathrm{C} \varepsilon \\
50.0 ; \mathrm{H}_{2} \mathrm{C} 3.60, \mathrm{CH}_{2} 52.0 ; \mathrm{CO} 174.1\end{array}$ \\
\hline Arg & 120.7 & 8.34 & 4.37 & $1.78,1.91$ & 56.3 & 30.6 & 177.3 & $\begin{array}{l}\mathrm{H} \gamma 1.62,1.66, \mathrm{C} \gamma 27.1 ; \mathrm{H} \delta 3.21, \mathrm{C} \delta 43.3 ; \mathrm{HN} \varepsilon 7.20^{\mathrm{a}} ; \mathrm{C} \zeta \\
159.6\end{array}$ \\
\hline $\operatorname{Arg}(\mathrm{Me})$ & 120.7 & 8.33 & 4.36 & $1.78,1.90$ & 56.4 & 30.7 & 177.3 & $\begin{array}{l}\mathrm{H} \gamma 1.62,1.65, \mathrm{C} \gamma 27.1 ; \mathrm{H} \delta 3.21, \mathrm{C} \delta 43.3 ; \mathrm{HN} \varepsilon 6.97^{\mathrm{a}} ; \mathrm{C} \zeta \\
\quad 159.3 ; \mathrm{HN \eta} 6.85^{\mathrm{a}} ; \mathrm{H}_{3} \mathrm{C} 2.82, \mathrm{CH}_{3} 30.2\end{array}$ \\
\hline $\operatorname{Arg}(\mathrm{Me})_{2}$ symmetric (SDMA) & 120.7 & 8.33 & 4.36 & $1.78,1.90$ & 56.4 & 30.7 & 177.3 & $\begin{array}{l}\mathrm{H} \gamma 1.62,1.65, \mathrm{C} \gamma 27.1 ; \mathrm{H} \delta 3.22, \mathrm{C} \delta 43.1 ; \mathrm{HN} \varepsilon 6.77^{\mathrm{a}}, \mathrm{NH} \varepsilon \\
\quad 115.9 ; \mathrm{C} \zeta 158.7 ; \mathrm{HN \eta} 6.78^{\mathrm{a}} ;\left(\mathrm{H}_{3} \mathrm{C}\right)_{2} 2.81,2.82,\left(\mathrm{CH}_{3}\right)_{2} \\
30.1\end{array}$ \\
\hline $\operatorname{Arg}(\mathrm{Me})_{2}$ asymmetric (ADMA) & 120.7 & 8.33 & 4.37 & $1.78,1.90$ & 56.4 & 30.7 & 177.3 & $\begin{array}{l}\mathrm{H} \gamma 1.63,1.66, \mathrm{C} \gamma 27.3 ; \mathrm{H} \delta 3.26, \mathrm{C} \delta 44.1 ; \mathrm{HN} \varepsilon 6.79^{\mathrm{a}}, \mathrm{NH} \varepsilon \\
119.5 ; \mathrm{C} \zeta 158.8 ; \mathrm{HN \eta} 6.71^{\mathrm{a}}, \mathrm{NH} \eta 107.9 ;\left(\mathrm{H}_{3} \mathrm{C}\right)_{2} 3.00, \\
\left(\mathrm{CH}_{3}\right)_{2} 40.3\end{array}$ \\
\hline Argpyrimidine (Apy) & 121.1 & 8.31 & 4.37 & $1.80,1.92$ & 56.6 & 30.8 & 177.5 & $\begin{array}{l}\mathrm{H} \gamma 1.64,1.69, \mathrm{C} \gamma 27.5 ; \mathrm{H} \delta 3.38, \mathrm{C} \delta \text { 43.5; C } \zeta 156.6 ; 3 \mathrm{C} \\
\quad 141.0 ; 4 \mathrm{C} 160.9 ;\left(\mathrm{H}_{3} \mathrm{C}\right)_{2} 2.36,\left(\mathrm{CH}_{3}\right)_{2} 20.1\end{array}$ \\
\hline Cit & 121.1 & 8.32 & 4.34 & $1.74,1.86$ & 56.6 & 30.8 & 177.6 & $\begin{array}{l}\mathrm{H} \gamma 1.51,1.56, \mathrm{C} \gamma 28.2 ; \mathrm{H} \delta 3.11, \mathrm{C} \delta 42.0 ; \mathrm{HN \varepsilon} 6.33^{\mathrm{a}}, \mathrm{NH} \varepsilon \\
\quad 123.7 ; \mathrm{C} \zeta 164.3 ; \mathrm{H}_{2} \mathrm{~N} 5.56^{\mathrm{a}}\end{array}$ \\
\hline Pro (trans) & - & - & 4.45 & $1.99,2.29$ & 63.7 & 32.0 & 178.1 & $\mathrm{H} \gamma$ 2.04, $\mathrm{C} \gamma 27.2 ; \mathrm{H} \delta 3.64,3.67, \mathrm{C} \delta 49.8$ \\
\hline Pro $(c i s, \sim 11.5 \%)^{\mathrm{b}}$ & - & - & 4.63 & $2.17,2.38$ & 63.0 & 34.6 & n.d. ${ }^{\mathrm{c}}$ & $\mathrm{H} \gamma 1.87,1.96, \mathrm{C} \gamma 24.7 ; \mathrm{H} \delta 3.54,3.61, \mathrm{C} \delta 50.3$ \\
\hline 4-Hyp (trans) & - & - & 4.56 & $2.12,2.36$ & 62.2 & 39.7 & 177.5 & 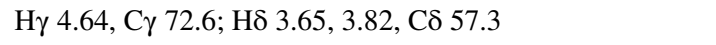 \\
\hline 4-Hyp $(\text { cis } \sim 9 \%)^{\mathrm{b}}$ & - & - & 4.58 & $2.28,2.52$ & 62.2 & 42.3 & n.d. ${ }^{\mathrm{c}}$ & 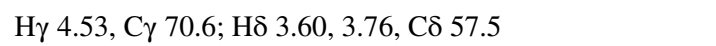 \\
\hline Asn & 118.8 & 8.47 & 4.76 & $2.80,2.86$ & 53.3 & 38.9 & 176.3 & $\mathrm{C} \gamma$ 177.4; $\mathrm{H}_{2} \mathrm{~N} \delta 6.91,7.61, \mathrm{NH}_{2} \delta 112.8$ \\
\hline Asn (GlcNAc) & 118.8 & 8.49 & 4.78 & $2.82,2.85$ & 52.9 & 39.3 & 176.1 & $\begin{array}{l}\mathrm{C} \gamma \text { 175.5; } \mathrm{H}_{2} \mathrm{~N} \delta 8.67, \mathrm{NH}_{2} \mathrm{\delta} 131.8 ; \mathrm{H} 15.04, \mathrm{C} 181.1 ; \mathrm{H} 2 \\
\text { 3.81, C2 57.1; } \mathrm{H} 33.60, \mathrm{C} 377.1 ; \mathrm{H} 43.47, \mathrm{C} 472.3 ; \mathrm{H} 5 \\
\text { 3.51, C5 80.4; } \mathrm{H}_{2} \mathrm{C} 63.75,3.88, \mathrm{CH}_{2} 6 \text { 63.4; } \mathrm{Ac}(\mathrm{HN} 8.18, \\
\left.\mathrm{NH} 122.1, \mathrm{CO} 177.6, \mathrm{H}_{3} \mathrm{C} 2.00, \mathrm{CH}_{3} 24.9\right)\end{array}$ \\
\hline Glu & 120.7 & 8.50 & 4.34 & $1.98,2.11$ & 56.7 & 29.6 & 177.3 & $\mathrm{H} \gamma 2.34, \mathrm{C} \gamma 35.1 ; \mathrm{C} \delta 182.8$ \\
\hline$\gamma$-Carboxy glutamic acid (Gla) & 120.2 & 8.56 & 4.37 & $2.20,2.36$ & 55.7 & 33.5 & 177.1 & $\mathrm{H} \gamma$ 3.27, C $\gamma 54.9 ; \mathrm{C} \delta 1 / \mathrm{C} \delta 2179.1$ \\
\hline Gly & 109.1 & 8.42 & 4.01 & - & 45.5 & - & 175.1 & \\
\hline
\end{tabular}

${ }^{a}$ Line broadening observed indicating possible multiple conformations or solvent exchange

${ }^{\mathrm{b}}$ The proportion of minor peptide conformations containing cis-proline or cis-hydroxyproline were estimated by integration of 3-4 well-resolved signals in the ${ }^{1} \mathrm{H}$ spectra

${ }^{c}$ n.d. $=$ not determined. Carbonyl resonances of the minor conformations could not be assigned unambiguously 


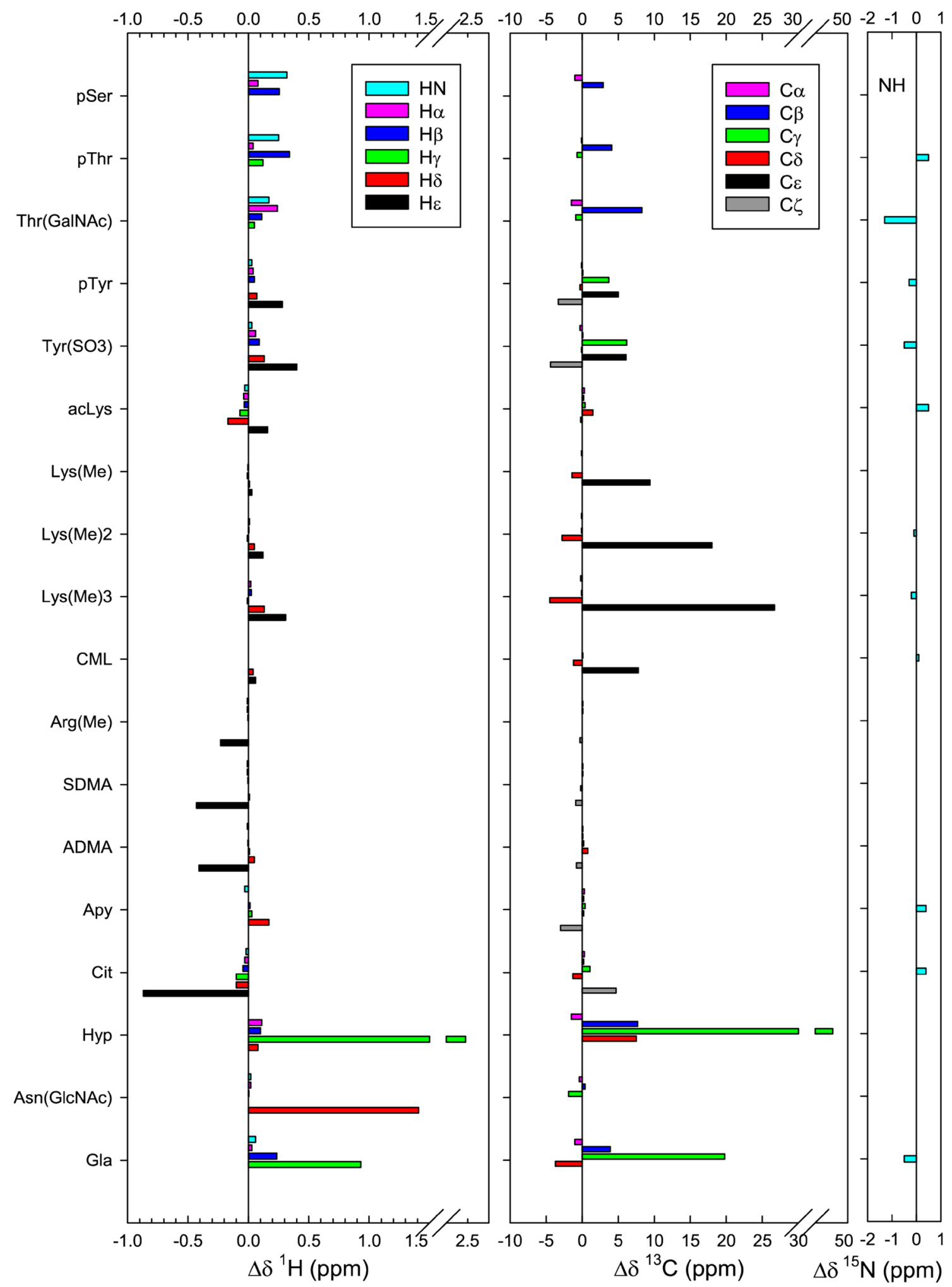

Fig. $2{ }^{1} \mathrm{H},{ }^{13} \mathrm{C}$ and ${ }^{15} \mathrm{~N}$ chemical shift differences $(\Delta \delta)$ between modified residues and their corresponding unmodified residues. CO differences are all $\leq 0.8 \mathrm{ppm}$ and have been omitted for clarity 
Fig. 3 Serine phosphorylation. a Superposition of ${ }^{1} \mathrm{H}-{ }^{15} \mathrm{~N}$ HSQC NMR spectra of random coil peptides containing serine (black contours) and phosphoserine (blue contours) as residue ' $X$ '. The arrow shows the characteristic $\sim 0.3 \mathrm{ppm}$ downfield shift of $\mathrm{HN}$ upon phosphorylation. $\mathbf{b}^{1} \mathrm{H}-{ }^{13} \mathrm{C}$ HSQC NMR spectra with shifts of $\mathrm{H} \alpha / \mathrm{C} \alpha$ and $\mathrm{H} \beta / \mathrm{C} \beta$ marked with arrows
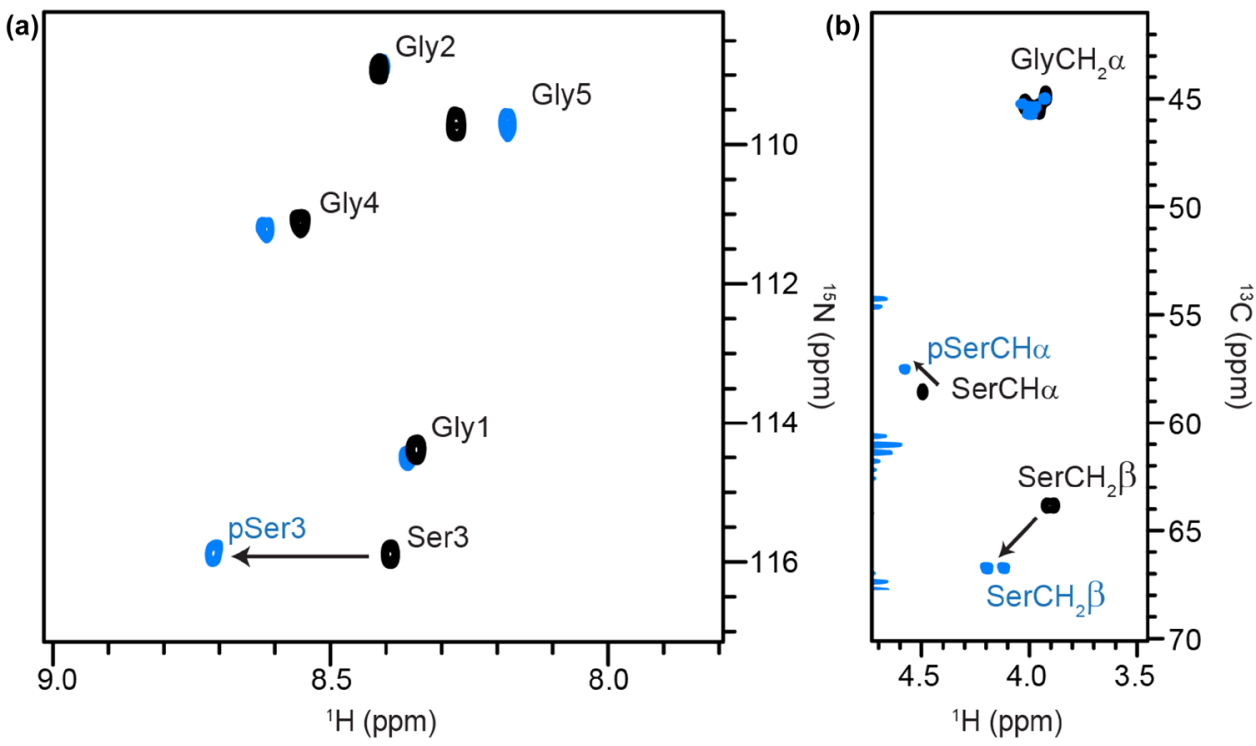

group might interact with the backbone $\mathrm{HN}$ of other residues nearby in space, and a shift might be observed in a non-modified residue [for examples see (Smet-Nocca et al. 2013; Bah et al. 2015; Dong et al. 2017)]. Hydrogen bonding of the phosphate moiety with either its own or other backbone amides might therefore have a significant role in the local structure and would not be present in the simple serine $\rightarrow$ glutamic acid substitution that is often used as a mimic of phosphoserine in proteins expressed recombinantly. Further evidence for the $\mathrm{pH}$ dependence and hydrogen bonding between the phosphate and backbone amide groups is shown by the smaller changes in chemical shifts between serine and phosphoserine when the spectra are acquired in $8 \mathrm{M}$ urea and pH 2.3 (Table S4); instead of the $0.32 \mathrm{ppm}$ downfield shift of $\mathrm{HN}$ observed in water at $\mathrm{pH} 5$, a $0.21 \mathrm{ppm}$ downfield shift of $\mathrm{HN}$ is observed in $8 \mathrm{M}$ urea at $\mathrm{pH}$ 2.3. Downfield shifts of $\mathrm{H} \beta / \mathrm{C} \beta$ resonances $(\sim+0.3 / \sim+3-4 \mathrm{ppm})$ occur upon phosphorylation of serine (Fig. 3) and threonine, due to the closer proximity of these nuclei to the phosphate group. Phosphorylation at serine/threonine residues preceding proline can also affect cis/trans isomerisation of the prolyl peptide bond (Theillet et al. 2012a).

In contrast, tyrosine phosphorylation does not cause a characteristic downfield shift of $\mathrm{HN}$ as observed for serine and threonine. It has been reported that the modification is most noticeable in the ${ }^{1} \mathrm{H}-{ }^{13} \mathrm{C}$ spectra by the downfield shifts of $\mathrm{H} \varepsilon / \mathrm{C} \varepsilon(\sim+0.3 / \sim+3 \mathrm{ppm})$ (Theillet et al. 2012a; Bienkiewicz and Lumb 1999). As shown in Table 1, we observed shifts of $\mathrm{C} \gamma(+3.7 \mathrm{ppm}), \mathrm{H} \varepsilon / \mathrm{C} \varepsilon(+0.28 /+5.0 \mathrm{ppm})$ and $\mathrm{C} \zeta$ $(-3.3 \mathrm{ppm})$ resonances. Although changes in the backbone chemical shifts of residues flanking phosphotyrosine have been observed in other studies and used for mapping tyrosine phosphorylation sites (Theillet et al. 2012a), we observed only a $0.17 \mathrm{ppm}$ downfield shift for Gly5 HN, however this might be due to the achirality of glycine or the short peptides of only five residues used in our study.

\section{Sulfation of tyrosine}

To our knowledge, there are no reports of NMR studies on tyrosine sulfation, in which the anionic sulfate moiety is transferred from phosphoadenosine phosphosulfate to tyrosine side chains (Walsh et al. 2005). As with tyrosine phosphorylation, this modification on the distal end of the side chain does not cause significant backbone chemical shift changes but causes changes in the aromatic nuclei shifts that are in the same direction but larger than those caused by phosphorylation: $\mathrm{C} \gamma(+6.2 \mathrm{ppm}), \mathrm{H} \varepsilon / \mathrm{C} \varepsilon(+0.40 /+6.1 \mathrm{ppm})$ and $\mathrm{C} \zeta(-4.4 \mathrm{ppm})$.

\section{Acetylation, methylation and carboxymethylation of lysine}

Lysine acetylation converts the terminal positively charged $\zeta \mathrm{NH}_{3}{ }^{+}$group into a neutral moiety whereas lysine methylation maintains the positive charge. In contrast, lysine carboxymethylation introduces a negatively-charged carboxylic acid, which forms a side-chain zwitterion at neutral $\mathrm{pH}$ (and pH 5.0 as in this study) because the alkylated $\zeta \mathrm{NH}_{2}{ }^{+}$remains protonated. These electrostatic changes can alter interactions of the lysine side chain; for example, the interactions of histone lysine residues with negatively-charged DNA are modulated by lysine acetylation and methylation in the 'histone code' (Muller and Muir 2015). As has previously been noted for proteins (Theillet et al. 2012a; Liokatis et al. 2010), acetylation of lysine in the random coil peptide results in small changes in backbone HN/NH resonances $(-0.03 /+0.5 \mathrm{ppm})$. However, the appearance of a new amide resonance for $\mathrm{H} \zeta /$ 
$\mathrm{N} \zeta$ at 7.94/127.3 ppm serves as an indicator of acetylation (Theillet et al. 2012a; Liokatis et al. 2010; Smet-Nocca et al. 2010). Small shifts in the ${ }^{1} \mathrm{H}-{ }^{15} \mathrm{~N}$ crosspeaks of neighbouring residues have been used to locate lysine acetylation sites in proteins (Theillet et al. 2012a; Liokatis et al. 2010), however we only observed a change in Gly5 HN/NH of $-0.03 / 0.1 \mathrm{ppm}$. Whereas $\mathrm{H} \varepsilon / \mathrm{C} \varepsilon$ resonances of acetyllysine appear at 3.16/42.0 ppm, those of lysine, mono-, di- and tri-methyllysine appear at 3.00/42.2 ppm, 3.03/51.6 ppm, 3.12/60.2 ppm, and 3.31/68.9 ppm, respectively (Fig. 4), allowing these different PTMs to be distinguished, as demonstrated by Thiellet et al. (2012a, b). Characteristic shifts are also observed for $\mathrm{H} \delta / \mathrm{C} \delta$ and for the added methyl groups $\mathrm{CH}_{3}$ 2.70/35.6 ppm, $\left(\mathrm{CH}_{3}\right)_{2} 2.86 / 45.4 \mathrm{ppm}$ and $\left(\mathrm{CH}_{3}\right)_{3}$ 3.10/55.5 ppm (Fig. 4). In contrast to acetylation and methylation, lysine carboxymethylation is a non-enzymatic PTM and is a common advanced glycation end product. The $\mathrm{He} /$ C $\varepsilon$ resonance shifts to $3.06 / 50.0 \mathrm{ppm}$ and an indicative ${ }^{1} \mathrm{H}-{ }^{13} \mathrm{C}$ crosspeak corresponding to the carboxymethyl $\mathrm{CH}_{2}$ appears at 3.60/52.0 ppm, allowing this modification to be distinguished from other lysine PTMs. The $\mathrm{pH}$ dependence of the ${ }^{1} \mathrm{H}$ chemical shifts from $\mathrm{pH} 2-9$ and the limits of the

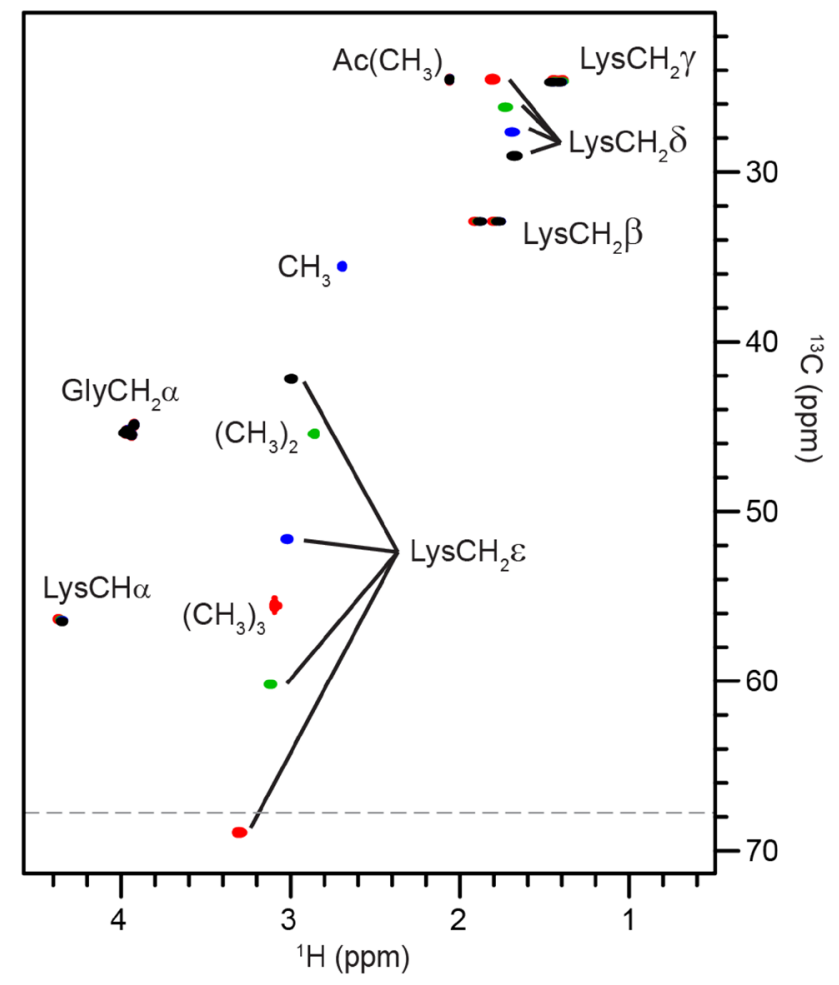

Fig. 4 Lysine methylation. Superposition of ${ }^{1} \mathrm{H}-{ }^{13} \mathrm{C}$ HSQC NMR spectra of random coil peptides containing lysine (black contours), methyllysine (blue contours), dimethyllysine (green contours) and trimethyllysine (red contours) as residue ' $\mathrm{X}$ '. The characteristic $\mathrm{H} \delta / \mathrm{C} \delta$, $\mathrm{H} \varepsilon / \mathrm{C} \varepsilon$ and methyl group crosspeaks are labelled. The grey dashed line at $68 \mathrm{ppm}$ indicates the wider sweep width of the ${ }^{1} \mathrm{H}-{ }^{13} \mathrm{C}$ HSQC spectrum acquired for $\mathrm{Lys}\left(\mathrm{CH}_{3}\right)_{3}$
${ }^{1} \mathrm{H},{ }^{15} \mathrm{~N}$ and ${ }^{13} \mathrm{C}$ chemical shifts were determined and are shown in Figure S1 and Table S6, respectively. Only the $\mathrm{CH}_{2}$ and carbonyl resonances of the carboxymethyl group showed significant $\mathrm{pH}$ dependence $\left(\Delta \delta \mathrm{CH}_{2}=-0.24 /+1.3\right.$, $\Delta \delta \mathrm{CO}=2.0 \mathrm{ppm}$ ) on increasing $\mathrm{pH}$. The $\mathrm{pKa}$ of the carboxymethyl carboxyl group was estimated to be $\leq 2$ from Figure S1.

\section{Methylation of arginine and modification to form argpyrimidine and citrulline}

Arginine can also be modified by methylation, which is an enzymatic modification, or by various non-enzymatic modifications to form advanced glycation end products such as argpyrimidine, which are found in tissues under oxidative stress. Whereas mono- and symmetric dimethylation of arginine results in very small shifts in $\mathrm{H} \delta / \mathrm{C} \delta$ and the appearance of methyl resonances at $2.82 / 30.2 \mathrm{ppm}$ and $2.81,2.82 / 30.1 \mathrm{ppm}$, respectively, asymmetric dimethylation causes a downfield shift of $\mathrm{H} \delta / \mathrm{C} \delta$ to 3.26/44.1 and the methyl resonances appear at 3.00/40.3 ppm. The $\mathrm{H} \varepsilon / \mathrm{N} \varepsilon$ and $\mathrm{H} \eta / \mathrm{N} \eta$ resonances also show dispersion, however these are only observed at low $\mathrm{pH}$ because of fast exchange with the solvent (Theillet et al. 2012a; Liepinsh and Otting 1996). In argpyrimidine, new ${ }^{13} \mathrm{C}$ signals are observed for the aromatic nuclei, $\mathrm{H} \delta$ shifts downfield by $+0.17 \mathrm{ppm}$ and the two methyl groups can be distinguished from those of dimethylarginine by their upfield shifts at 2.36/20.1 ppm. Uncharged citrulline is formed by the deimination of positively-charged arginine by peptidylarginine deiminases and this PTM can alter protein structure, binding and immunogenicity (Fuhrmann et al. 2015; Gyorgy et al. 2006). Although the mass difference of 1 Da resulting from this PTM might be difficult to detect without high resolution mass spectrometry, citrulline can easily be distinguished from arginine in ${ }^{1} \mathrm{H}_{-}{ }^{13} \mathrm{C}$ NMR spectra by the $\mathrm{H} \gamma / \mathrm{C} \gamma$ resonances at 1.51 , $1.56 / 28.2 \mathrm{ppm}$ and $\mathrm{H} \delta / \mathrm{C} \delta$ resonances at $3.11 / 42.0 \mathrm{ppm}$, as well as the new carbonyl ${ }^{13} \mathrm{C}$ resonance at $164.3 \mathrm{ppm}$.

\section{$\mathrm{N}$ - and 0-glycosylation}

The most common glycosylation PTMs in eukaryotes are $\mathrm{O}$-glycosylation of serine or threonine and $\mathrm{N}$-glycosylation of asparagine, and involve either simple or highly complex branched carbohydrate chains (Walsh et al. 2005). The carbohydrate moieties are typically mobile and solvent-exposed, and can modify protein structures, solubility and immunogenicity (Bourre et al. 2018; Theillet et al. 2012a). The random coil shifts of Asn( $\beta$-D-GlcNAc), with which $\mathrm{N}$-glycan structures are linked to proteins, show a large downfield shift in the $\mathrm{H} \delta / \mathrm{N} \delta$ resonances to $8.67 / 131.8 \mathrm{ppm}$ in comparison to those of asparagine $\mathrm{H} \delta / \mathrm{N} \delta$ (6.91, 7.61/112.8 ppm). Furthermore, the crosspeak of the $\mathrm{H} 1 / \mathrm{C} 1$ anomeric carbon 
appears at 5.04/81.1 ppm, characteristic of the linkage to nitrogen in $\mathrm{N}$-glycans. This anomeric 'fingerprint' region of N-glycosylated proteins has been used to identify glycans and analyse their composition and linkage types on a several proteins under denaturing conditions (Schubert et al. 2015). In contrast, the anomeric H1/C1 crosspeak of $\operatorname{Thr}(\alpha-D-G a l N A c)$ appears at 4.93/101.4 ppm, which is characteristic of an O-linked sugar. The $\mathrm{H} \beta / \mathrm{C} \beta$ crosspeak of $\operatorname{Thr}(\alpha-\mathrm{D}-\mathrm{GalNAc})$ shifts to $4.42 / 78.1 \mathrm{ppm}$, while $\mathrm{H} \alpha / \mathrm{C} \alpha$ shifts to $4.63 / 60.5 \mathrm{ppm}$, allowing threonine glycosylation to be distinguished from threonine phosphorylation. Although we did not have access to Ser $(\alpha-D-G a l N A c)$ for comparison in this study, different orientations of the carbohydrate moiety at the glycosidic linkage have been reported for Thr(D-GalNAc) and Ser(D-GalNAc) in simple model peptides, independent of the anomeric configuration $(\alpha$ or $\beta)$, however chemical shift assignments were not reported (Corzana et al. 2007). For O-glycosylation, the peptide backbone might be constrained in an extended conformation by interactions between the sugar and backbone (Rani and Mallajosyula 2017; Elbaum and Zondlo 2014), consistent with the changes in chemical shifts observed for $\mathrm{Thr}$ (GalNAc) $\mathrm{CO}$ $(-0.8 \mathrm{ppm}), \mathrm{NH}(-1.3 \mathrm{ppm}), \mathrm{H} \alpha(+0.24 \mathrm{ppm})$ and Gly4 $\mathrm{NH}(-1.7 \mathrm{ppm})$. Furthermore, in threonine ${ }^{3} \mathrm{~J}_{\mathrm{HNHA}}=7.5 \mathrm{~Hz}$ whereas in $\operatorname{Thr}(\mathrm{GalNAc}){ }^{3} \mathrm{~J}_{\mathrm{HNHA}}=9.2 \mathrm{~Hz}$, indicating a more extended conformation in the glycosylated peptide. The possible 'extended' rather than 'random coil' nature of the Thr(GalNAc) peptide should therefore be noted when using the chemical shifts as reference values, to prevent potential helical content bias.

\section{Hydroxylation of proline}

Hydroxyproline has a key role in essential mammalian proteins such as collagen and hypoxia inducible factor 1-alpha (HIF-1 $\alpha$ ) (Walsh et al. 2005). Alongside C-terminal amidation and disulfide bond formation, it is also among the most common PTMs of conotoxins-venom peptides from cone snails that are characterised by stability, a high prevalence of PTMs and potent activity at their target receptors (Akondi et al. 2014). Hydroxylation of proline by prolyl 4-hydroxylase is the most prevalent PTM in humans and forms (2S,4R)-4-hydroxyproline (4-Hyp), which favours the trans-configuration and has a crucial role in stabilising the triple helix structure of collagen (Gorres and Raines 2010; Eberhardt et al. 1996). Due to the lack of an amide proton in proline and 4-hydroxyproline, the hydroxylation is most obvious in the downfield shifts of the ${ }^{1} \mathrm{H}-{ }^{13} \mathrm{C}$ crosspeaks $\mathrm{H} \beta$ / $\mathrm{C} \beta(+0.10 /+7.7 \mathrm{ppm}), \mathrm{H} \gamma / \mathrm{C} \gamma(+2.59 /+45.4 \mathrm{ppm})$ and $\mathrm{H} \delta /$ $\mathrm{C} \delta(+0.08 /+7.5 \mathrm{ppm})$ due to the presence of the deshielding hydroxy group on $\mathrm{C} \gamma$ (Fig. 2). The major conformations of both the proline- and 4-hydroxyproline-containing peptides were trans-, with minor cis- conformations that could be assigned (Table 1). In agreement with the literature (Eberhardt et al. 1996), hydroxylation at the $4 R$ position increases the population of the trans- configuration (Pro $11.5 \% \mathrm{cis}$-, 4-Hyp 9\% cis-). These cis- populations are likely to be higher in the random coil peptides than in natural proteins, however, due to the minimal constraints of the neighbouring glycine residues. Also in agreement with literature (Marx et al. 2006), in the cis- conformation of 4-hydroxyproline, there is a smaller chemical shift difference between the $C \beta$ and $\mathrm{C} \gamma$ resonances $(28.3 \mathrm{ppm})$ than in the trans-configuration (32.9 ppm).

\section{$\mathrm{Y}$-Carboxylation of glutamic acid}

Also common in conotoxins and having an important role in the folding of blood clotting factor coagulation protease factor IX (Walsh et al. 2005), $\gamma$-carboxylation of glutamic acid causes downfield shifts of the $\mathrm{H} \beta / \mathrm{C} \beta$ resonances $(+0.23 /+3.9 \mathrm{ppm})$ and $\mathrm{H} \gamma / \mathrm{C} \gamma$ resonances $(+0.93 /+19.8 \mathrm{ppm})$, making this modification easy to identify (Figs. 2 and 5). This PTM is often associated with $\mathrm{Ca}^{2+}$ binding and induction of helicity and several NMR

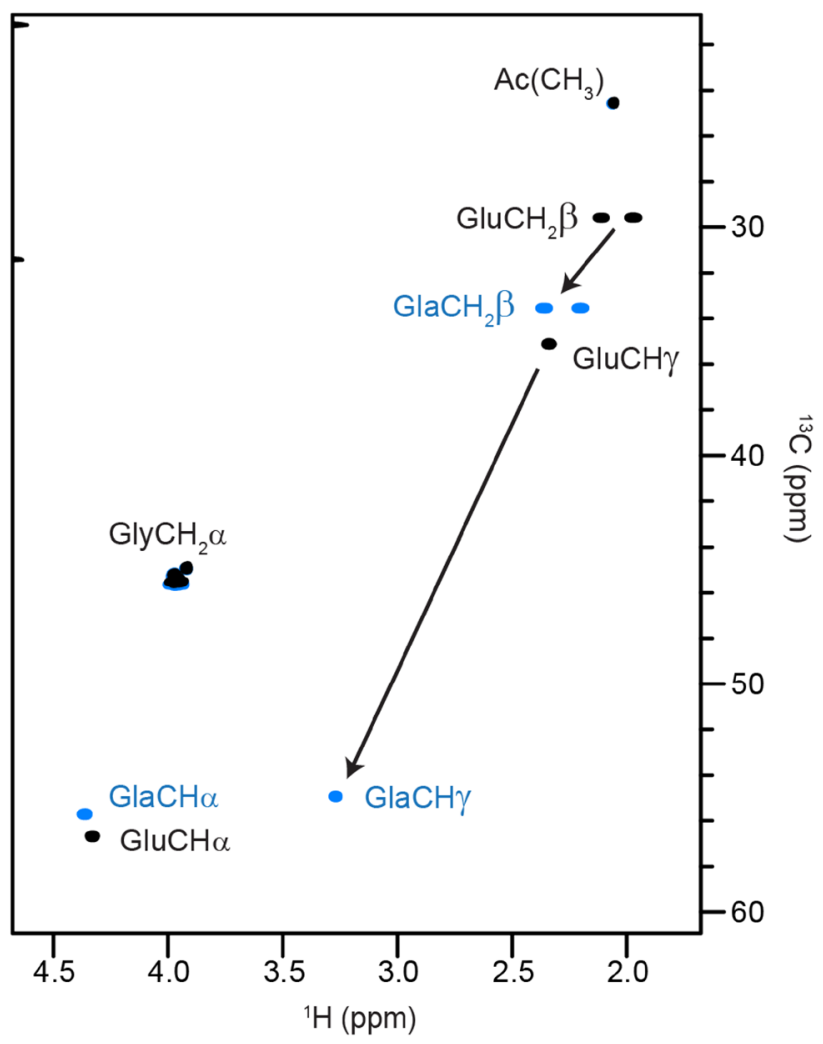

Fig. 5 Glutamic acid $\gamma$-carboxylation. Superposition of ${ }^{1} \mathrm{H}-{ }^{13} \mathrm{C}$ HSQC NMR spectra of random coil peptides containing glutamic acid (black contours) and $\gamma$-carboxyglutamate (blue contours) as residue ' $X$ '. The arrows show the characteristic downfield shifts of $\mathrm{H} \beta$ / $\mathrm{C} \beta$ and $\mathrm{H} \gamma / \mathrm{C} \gamma$ upon carboxylation 
structures of conotoxins containing $\gamma$-carboxyglutamate have been published with $\mathrm{Ca}^{2+}$ bound, however, the chemical shifts vary only marginally compared to those without $\mathrm{Ca}^{2+}$ bound (Marx et al. 2006). In contrast to the random coil $\mathrm{H} \alpha$ shift of $\gamma$-carboxyglutamate (4.37 ppm, Table 1), the average $\mathrm{H} \alpha$ shift of $\gamma$-carboxyglutamate in the conotoxin structures reviewed by Marx et al. is $4.16 \mathrm{ppm}$, which is due to its propensity to be found in helices (Marx et al. 2006). This illustrates the difference between the random coil shifts reported here and average shifts from structural databases and, moreover, how deviations from random coil shifts can indicate the presence of secondary structures. Similarly to serine and threonine phosphorylation discussed above, the additional carboxyl group in $\gamma$-carboxyglutamate might also interact with nearby residues in space and cause changes in their chemical shifts. The $\mathrm{pH}$ dependence of the ${ }^{1} \mathrm{H}$ chemical shifts from pH 2-9 and the limits of the ${ }^{1} \mathrm{H},{ }^{15} \mathrm{~N}$ and ${ }^{13} \mathrm{C}$ chemical shifts were determined and are shown in Figure $\mathrm{S} 2$ and Table S6, respectively. Chemical shift dependence on $\mathrm{pH}$ is observed for all the ${ }^{1} \mathrm{H}$ resonances but is most noticeable in the $\mathrm{H} \gamma / \mathrm{C} \gamma$ shifts $(\Delta \delta \mathrm{H} \gamma \mathrm{C} \gamma=0.39 / 6.0 \mathrm{ppm})$ and the two side chain carbonyls $(\Delta \delta C O=5.2 \mathrm{ppm})$. The titration curve appears to be biphasic, with pKa values of $\sim 2.7$ and 4.6. More detailed measurements would be needed to study the linked equilibria of the two carboxyl groups, as has been demonstrated for two glutamic acid residues in Bacillus circulans xylanase (McIntosh et al. 2011).

\section{Flanking glycine residues}

The chemical shifts of the glycine residues flanking the residue ' $X$ ' of interest are given in Table S3. The chemical shifts of the flanking residues are not reported in other random coil datasets (with the exception of a study of neighbour effects by Schwarzinger et al. 2001), but we have included them as they provide information about the internal consistency of the dataset and the effects of modifications on neighbouring residues. As shown in Table S3, the standard deviations, particularly of the resonances belonging to the terminal residues show very high consistency of the chemical shifts $\left(0.00 \mathrm{ppm} \leq \mathrm{std}\right.$. dev. ${ }^{1} \mathrm{H} \leq 0.09 \mathrm{ppm}$; $0.0 \mathrm{ppm} \leq$ std. dev. ${ }^{13} \mathrm{C} \leq 0.2 \mathrm{ppm} ; 0.1 \mathrm{ppm} \leq$ std. dev. ${ }^{15} \mathrm{~N} \leq 0.7 \mathrm{ppm}$ ), despite slight variations in $\mathrm{pH}$ and concentration between the samples (Table S2). As would be expected from the proximity of the variable residue ' $\mathrm{X}$ ' (residue 3), the highest standard deviations are observed for the resonances of residues Gly2 and Gly4. The Gly2 $\mathrm{HN}, \mathrm{C} \alpha$ and $\mathrm{CO}$ resonances are all upfield shifted and the $\mathrm{H} \alpha$ resonances downfield shifted when followed by proline or hydroxyproline, in agreement with observations made by Wishart et al. (1995) Gly4 HN resonances are downfield shifted when preceded by phosphoserine or phosphothreonine (+ $0.07 \mathrm{ppm})$, and hydroxyproline
$(+0.13 \mathrm{ppm})$, whereas the Gly4 $\mathrm{NH}$ is upfield shifted $(-1.7 \mathrm{ppm})$ when preceded by $\operatorname{Thr}(\mathrm{GalNAc})$. When residue ' $\mathrm{X}$ ' is tyrosine, phosphotyrosine or sulfotyrosine, Gly5 $\mathrm{HN}$ resonances are upfield shifted, particularly for tyrosine ( $-0.34 \mathrm{ppm}$, compared to the average shift of Gly5 HN). As shown by Wishart et al., the neighbouring residues can affect chemical shifts of the residue of interest as they influence the $\varphi$ and $\psi$ angle preferences (Wishart et al. 1995). For example, ${ }^{15} \mathrm{NH}$ shifts can be affected by the preceding residue $(i-1)$ by up to $4.5 \mathrm{ppm}$ because ${ }^{15} \mathrm{~N}$ shifts are correlated with the $\psi$ angle of the preceding residue (Wishart and Nip 1998). In contrast, the following residue $(i+1)$, particularly proline and aromatic amino acids, tends to affect $\mathrm{H} \alpha$ and $\mathrm{C} \alpha$ chemical shifts (Wishart and Nip 1998). Although glutamine has been suggested as a flanking residue that might provide better predictions of Ramachandran distribution (Ting et al. 2010; Kjaergaard and Poulsen 2011), we have used glycine as both preceding and following residues to allow for maximum conformational flexibility and for compatibility with other random coil datasets, allowing for broad application. Our observed random coil shifts of the standard amino acids are nevertheless in good agreement with the random coil shifts of residues followed by alanine (Wishart et al. 1995).

\section{Conclusion}

We have synthesised a set of random coil peptides containing common naturally-occurring protein PTMs and assigned the random coil NMR chemical shifts. We have highlighted distinctive NMR signatures of the PTMs and compared them with values reported in the literature. The random coil shifts can be used in conjunction with established random coil shifts of the standard amino acids to identify PTMs in proteins and peptides and to determine the presence of structural elements or structural propensity. Furthermore, the random coil shifts of the modified residues determined here can be added to the reference datasets of programs that use secondary chemical shifts to predict structural parameters or structures of proteins containing PTMs. This will help us to understand the role of PTMs in protein structure and function and will provide insights into protein regulation by PTMs in both normal cellular processes and disease.

Acknowledgements Open access funding provided by University of Vienna. We thank Philipp Schilling and Gilyana Kücükkaplan for assistance with peptide synthesis, Susanne Felsinger for assistance with acquiring NMR data, and Dr. Maria Matveenko for synthesis of the argpyrimidine building block.

Funding ACC is supported by a University of Queensland Development Fellowship (Project 613982). ACC and CFWB have been funded 
by the Vienna Science and Technology Fund (WWTF) through project LS17-008.

\section{Compliance with ethical standards}

Conflict of interest The authors declare that they have no conflict of interest.

Open Access This article is distributed under the terms of the Creative Commons Attribution 4.0 International License (http://creativeco mmons.org/licenses/by/4.0/), which permits unrestricted use, distribution, and reproduction in any medium, provided you give appropriate credit to the original author(s) and the source, provide a link to the Creative Commons license, and indicate if changes were made.

\section{References}

Aebersold R, Agar JN, Amster IJ, Baker MS, Bertozzi CR, Boja ES, Costello CE, Cravatt BF, Fenselau C, Garcia BA, Ge Y, Gunawardena J, Hendrickson RC, Hergenrother PJ, Huber CG, Ivanov AR, Jensen ON, Jewett MC, Kelleher NL, Kiessling LL, Krogan NJ, Larsen MR, Loo JA, Ogorzalek Loo RR, Lundberg E, MacCoss MJ, Mallick P, Mootha VK, Mrksich M, Muir TW, Patrie SM, Pesavento JJ, Pitteri SJ, Rodriguez H, Saghatelian A, Sandoval W, Schluter H, Sechi S, Slavoff SA, Smith LM, Snyder MP, Thomas PM, Uhlen M, Van Eyk JE, Vidal M, Walt DR, White FM, Williams ER, Wohlschlager T, Wysocki VH, Yates NA, Young NL, Zhang B (2018) How many human proteoforms are there? Nat Chem Biol 14:206-214

Akondi KB, Muttenthaler M, Dutertre S, Kaas Q, Craik DJ, Lewis RJ, Alewood PF (2014) Discovery, synthesis, and structureactivity relationships of conotoxins. Chem Rev 114:5815-5847

Armstrong DA, Kaas Q, Rosengren KJ (2018) Prediction of disulfide dihedral angles using chemical shifts. Chem Sci 9:6548-6556

Bah A, Vernon RM, Siddiqui Z, Krzeminski M, Muhandiram R, Zhao C, Sonenberg N, Kay LE, Forman-Kay JD (2015) Folding of an intrinsically disordered protein by phosphorylation as a regulatory switch. Nature 519:106-109

Barber KW, Rinehart J (2018) The ABCs of PTMs. Nat Chem Biol 14:188-192

Berjanskii MV, Wishart DS (2005) A simple method to predict protein flexibility using secondary chemical shifts. J Am Chem Soc 127:14970-14971

Bienkiewicz EA, Lumb KJ (1999) Random-coil chemical shifts of phosphorylated amino acids. J Biomol NMR 15:203-206

Bourre G, Cantrelle FX, Kamah A, Chambraud B, Landrieu I, SmetNocca C (2018) Direct crosstalk between O-GlcNAcylation and phosphorylation of tau protein investigated by NMR spectroscopy. Front Endocrinol 9:595

Conibear AC, Watson EE, Payne RJ, Becker CFW (2018) Native chemical ligation in protein synthesis and semi-synthesis. Chem Soc Rev 47:9046-9068

Cornilescu G, Delaglio F, Bax A (1999) Protein backbone angle restraints from searching a database for chemical shift and sequence homology. J Biomol NMR 13:289-302

Corzana F, Busto JH, Jimenez-Oses G, de Luis MG, Asensio JL, Jimenez-Barbero J, Peregrina JM, Avenoza A (2007) Serine versus threonine glycosylation: the methyl group causes a drastic alteration on the carbohydrate orientation and on the surrounding water shell. J Am Chem Soc 129:9458-9467
Dong X, Gong Z, Lu Y-B, Liu K, Qin L-Y, Ran M-L, Zhang C-L, Liu Z, Zhang W-P, Tang C (2017) Ubiquitin S65 phosphorylation engenders a $\mathrm{pH}$-sensitive conformational switch. Proc Natl Acad Sci USA 114:6770-6775

Dose A, Liokatis S, Theillet FX, Selenko P, Schwarzer D (2011) NMR profiling of histone deacetylase and acetyl-transferase activities in real time. ACS Chem Biol 6:419-424

Du JT, Li YM, Wei W, Wu GS, Zhao YF, Kanazawa K, Nemoto T, Nakanishi H (2005) Low-barrier hydrogen bond between phosphate and the amide group in phosphopeptide. J Am Chem Soc 127:16350-16351

Dyson HJ, Wright PE (1991) Defining solution conformations of small linear peptides. Annu Rev Biophys Biophys Chem 20:519-538

Eberhardt ES, Panisik N Jr, Raines RT (1996) Inductive effects on the energetics of prolyl peptide bond isomerization: implications for collagen folding and stability. J Am Chem Soc 118:12261-12266

Elbaum MB, Zondlo NJ (2014) OGlcNAcylation and phosphorylation have similar structural effects in alpha-helices: post-translational modifications as inducible start and stop signals in alpha-helices, with greater structural effects on threonine modification. Biochemistry 53:2242-2260

Ellmer D, Brehs M, Haj-Yahya M, Lashuel HA, Becker CFW (2019) Single posttranslational modifications in the central repeat domains of Tau4 impact its aggregation and tubulin binding. Angew Chem Int Ed Engl 58:1616-1620

Fuhrmann J, Clancy KW, Thompson PR (2015) Chemical biology of protein arginine modifications in epigenetic regulation. Chem Rev 115:5413-5461

Gorres KL, Raines RT (2010) Prolyl 4-hydroxylase. Crit Rev Biochem Mol Biol 45:106-124

Gyorgy B, Toth E, Tarcsa E, Falus A, Buzas EI (2006) Citrullination: a posttranslational modification in health and disease. Int J Biochem Cell Biol 38:1662-1677

Harris RK, Becker ED, de Menezes SMC, Granger P, Hoffman RE, Zilm KW (2008) Further conventions for NMR shielding and chemical shifts (IUPAC Recommendations 2008). Pure Appl Chem 80:59-84

Kjaergaard M, Poulsen FM (2011) Sequence correction of random coil chemical shifts: correlation between neighbor correction factors and changes in the Ramachandran distribution. J Biomol NMR 50:157-165

Lang K, Chin JW (2014) Cellular incorporation of unnatural amino acids and bioorthogonal labeling of proteins. Chem Rev 114:4764-4806

Lewis YE, Galesic A, Levine PM, De Leon CA, Lamiri N, Brennan CK, Pratt MR (2017) O-GlcNAcylation of alpha-Synuclein at Serine 87 reduces aggregation without affecting membrane binding. ACS Chem Biol 12:1020-1027

Liepinsh E, Otting G (1996) Proton exchange rates from amino acid side chains-implications for image contrast. Magn Reson Med 35:30-42

Liokatis S, Dose A, Schwarzer D, Selenko P (2010) Simultaneous detection of protein phosphorylation and acetylation by highresolution NMR spectroscopy. J Am Chem Soc 132:14704-14705

Liu CC, Schultz PG (2010) Adding new chemistries to the genetic code. Annu Rev Biochem 79:413-444

Martinez-Saez N, Peregrina JM, Corzana F (2017) Principles of mucin structure: implications for the rational design of cancer vaccines derived from MUC1-glycopeptides. Chem Soc Rev 46:7154-7175

Marx UC, Daly NL, Craik DJ (2006) NMR of conotoxins: structural features and an analysis of chemical shifts of post-translationally modified amino acids. Magn Reson Chem 44:S41-S50

McIntosh LP, Naito D, Baturin SJ, Okon M, Joshi MD, Nielsen JE (2011) Dissecting electrostatic interactions in Bacillus circulans 
xylanase through NMR-monitored $\mathrm{pH}$ titrations. J Biomol NMR 51:5-19

Mielke SP, Krishnan VV (2004) An evaluation of chemical shift indexbased secondary structure determination in proteins: influence of random coil chemical shifts. J Biomol NMR 30:143-153

Mielke SP, Krishnan VV (2009) Characterization of protein secondary structure from NMR chemical shifts. Prog Nucl Magn Reson Spectrosc 54:141-165

Muller MM, Muir TW (2015) Histones: at the crossroads of peptide and protein chemistry. Chem Rev 115:2296-2349

Platzer G, Okon M, McIntosh LP (2014) pH-dependent random coil (1) $\mathrm{H},(13) \mathrm{C}$, and (15) $\mathrm{N}$ chemical shifts of the ionizable amino acids: a guide for protein $\mathrm{pK}$ a measurements. J Biomol NMR 60:109-129

Plaxco KW, Morton CJ, Grimshaw SB, Jones JA, Pitkeathly M, Campbell ID, Dobson CM (1997) The effects of guanidine hydrochloride on the 'random coil' conformations and NMR chemical shifts of the peptide series GGXGG. J Biomol NMR 10:221-230

Rani L, Mallajosyula SS (2017) Phosphorylation versus O-GlcNAcylation: computational insights into the differential influences of the two competitive post-translational modifications. J Phys Chem B 121:10618-10638

Schubert M, Walczak MJ, Aebi M, Wider G (2015) Posttranslational modifications of intact proteins detected by NMR spectroscopy: application to glycosylation. Angew Chem Int Ed Engl 54:7096-7100

Schwarzinger S, Kroon GJ, Foss TR, Wright PE, Dyson HJ (2000) Random coil chemical shifts in acidic $8 \mathrm{M}$ urea: implementation of random coil shift data in NMRView. J Biomol NMR 18:43-48

Schwarzinger S, Kroon GJ, Foss TR, Chung J, Wright PE, Dyson HJ (2001) Sequence-dependent correction of random coil NMR chemical shifts. J Am Chem Soc 123:2970-2978

Schweida D, Barraud P, Regl C, Loughlin FE, Huber CG, Cabrele C, Schubert M (2019) The NMR signature of gluconoylation: a frequent $\mathrm{N}$-terminal modification of isotope-labeled proteins. $\mathrm{J}$ Biomol NMR 73:71-79

Shen Y, Bax A (2013) Protein backbone and sidechain torsion angles predicted from NMR chemical shifts using artificial neural networks. J Biomol NMR 56:227-241

Shen Y, Lange O, Delaglio F, Rossi P, Aramini JM, Liu G, Eletsky A, Wu Y, Singarapu KK, Lemak A, Ignatchenko A, Arrowsmith CH, Szyperski T, Montelione GT, Baker D, Bax A (2008) Consistent blind protein structure generation from NMR chemical shift data. Proc Natl Acad Sci USA 105:4685-4690

Shen Y, Delaglio F, Cornilescu G, Bax A (2009a) TALOS + : a hybrid method for predicting protein backbone torsion angles from NMR chemical shifts. J Biomol NMR 44:213-223

Shen Y, Vernon R, Baker D, Bax A De (2009b) novo protein structure generation from incomplete chemical shift assignments. J Biomol NMR 43:63-78

Smet-Nocca C, Wieruszeski JM, Melnyk O, Benecke A (2010) NMR-based detection of acetylation sites in peptides. J Pept Sci $16: 414-423$

Smet-Nocca C, Launay H, Wieruszeski JM, Lippens G, Landrieu I (2013) Unraveling a phosphorylation event in a folded protein by
NMR spectroscopy: phosphorylation of the Pin1 WW domain by PKA. J Biomol NMR 55:237-323

Theillet FX, Smet-Nocca C, Liokatis S, Thongwichian R, Kosten J, Yoon MK, Kriwacki RW, Landrieu I, Lippens G, Selenko P (2012a) Cell signaling, post-translational protein modifications and NMR spectroscopy. J Biomol NMR 54:217-236

Theillet FX, Liokatis S, Jost JO, Bekei B, Rose HM, Binolfi A, Schwarzer D, Selenko P (2012b) Site-specific mapping and timeresolved monitoring of lysine methylation by high-resolution NMR spectroscopy. J Am Chem Soc 134:7616-7619

Theillet FX, Rose HM, Liokatis S, Binolfi A, Thongwichian R, Stuiver M, Selenko P (2013) Site-specific NMR mapping and timeresolved monitoring of serine and threonine phosphorylation in reconstituted kinase reactions and mammalian cell extracts. Nat Protoc 8:1416-1432

Ting D, Wang G, Shapovalov M, Mitra R, Jordan MI, Dunbrack RL Jr (2010) Neighbor-dependent ramachandran probability distributions of amino acids developed from a hierarchical dirichlet process model. PLoS Comput Biol 6:e1000763

Vranken WF, Boucher W, Stevens TJ, Fogh RH, Pajon A, Llinas M, Ulrich EL, Markley JL, Ionides J, Laue ED (2005) The CCPN data model for NMR spectroscopy: development of a software pipeline. Proteins 59:687-696

Walsh CT, Garneau-Tsodikova S, Gatto GJ Jr (2005) Protein posttranslational modifications: the chemistry of proteome diversifications. Angew Chem Int Ed Engl 44:7342-7372

Wang CK, Craik DJ (2019) Toward Structure Determination of Disulfide-Rich Peptides Using Chemical Shift-Based Methods. J Phys Chem B 123:1903-1912

Wilson D, Daly NL (2018) Nuclear magnetic resonance seq (NMRseq): a new approach to peptide sequence tags. Toxins 10:437

Wishart DS, Nip AM (1998) Protein chemical shift analysis: a practical guide. Biochem Cell Biol 76:153-163

Wishart DS, Sykes BD, Richards FM (1992) The chemical shift index: a fast and simple method for the assignment of protein secondary structure through NMR spectroscopy. Biochemistry 31:1647-1651

Wishart DS, Bigam CG, Holm A, Hodges RS, Sykes BD (1995a) 1H, $13 \mathrm{C}$ and $15 \mathrm{~N}$ random coil NMR chemical shifts of the common amino acids. I. Investigations of nearest-neighbor effects. J Biomol NMR 5:67-81

Wishart DS, Bigam CG, Yao J, Abildgaard F, Dyson HJ, Oldfield E, Markley JL, Sykes BD (1995b) 1H, 13C and $15 \mathrm{~N}$ chemical shift referencing in biomolecular NMR. J Biomol NMR 6:135-140

Wüthrich K (1986) NMR of Proteins and Nucleic Acids. Wiley, New York

Zhang Y, Park KY, Suazo KF, Distefano MD (2018) Recent progress in enzymatic protein labelling techniques and their applications. Chem Soc Rev 47:9106-9136

Publisher's Note Springer Nature remains neutral with regard to jurisdictional claims in published maps and institutional affiliations. 